\title{
Pressure-forced meteotsunami occurrences in the eastern Yellow Sea over the past decade (2010-2019): monitoring guidelines
}

\author{
Myung-Seok Kim ${ }^{1}$, Seung-Buhm Woo ${ }^{1}$, Hyunmin Eom ${ }^{2}$, and Sung Hyup You ${ }^{2}$ \\ ${ }^{1}$ Department of Ocean Sciences, Inha University, Incheon 22212, Republic of Korea \\ $5 \quad{ }^{2}$ Marine Meteorology Division, Korea Meteorological Administration, Seoul 07062, Republic of Korea \\ Correspondence to: Myung-Seok Kim (kmspban@gmail.com)
}

\begin{abstract}
The eastern Yellow Sea meteotsunami occurrences between 2010 and 2019 and guidelines derived using favourable conditions of pressure disturbance (10 min rate of air pressure change) for meteotsunami generation are described. A total of 34 meteotsunami events over the past decade can be classified based on a current meteotsunami monitoring and observation 10 system. 1 min intervals of mean sea level pressure and sea level observations from 89 meteorological stations and 16 tide gauges are analysed. Most of the classified meteotsunami events $(76 \%, 26 / 34)$ in the eastern Yellow Sea are found to be between February and June during the winter-to-summer transition, which shows a strong seasonal trend. The meteotsunami occurrences are spatially frequent at the DaeHeuksando (DH) tide gauge, known as a beacon tide gauge of the observation system. It appears that the specific characteristics (intensity, occurrence rate, and propagation) of the pressure disturbance are

15 in common on extreme meteotsunami events that are classified by applying the hazardous meteotsunami conditions among the 34 events. For a risk level assessment of the eastern Yellow Sea meteotsunami occurrences, favourable conditions of the pressure disturbance for meteotsunami generation are utilized. Overall, this study can provide useful and practical guidelines such as operation period, potential hot spot, and risk level to monitoring system operators when operating the monitoring system of the Yellow Sea.
\end{abstract}

\section{Introduction}

Globally, monitoring high-frequency sea level oscillations is important issues for warning system operators and policymakers (Šepić et al., 2015a) as frequent coastal floods have been reported from coastal communities (Vilibić et al., 2014). The highfrequency sea level oscillations such as infragravity waves, seiches, tsunamis, and meteotsunamis, have periods of several minutes to hours (Rabinovich, 2009). Among them, meteotsunamis are high-frequency and tsunami-like sea level oscillations (Monserrat et al., 2006) that dominant in the tsunami frequency band ( $2 \mathrm{~min}$ to $2 \mathrm{~h}$ ). However, unlike tsunami waves, which are of seismic origin, meteotsunamis are atmospherically generated and amplified by multi-resonant mechanism (Pattiaratchi and Wijeratne, 2015). The well-known mechanism of meteotsunamis (Monserrat et al., 2006) are as following three stages: (i) as the first stage, long waves generated by air pressure disturbance in the open sea; (ii) a resonant amplification caused by propagating the forced long waves locked to the pressure disturbance with a similar speed, which is the Proudman resonance 
30 (Proudman, 1929); and (iii) internal resonances in shelf, bays, or harbours between the dominant period of the pre-amplified waves and their fundamental periods. As a result, sea level oscillations in the open sea of several centimetres can be amplified up to destructive amplitudes of several meters high along the shoreline. The pressure-forced meteotsunami occurrences, which are known to have temporal and spatial occurrences more frequent than seismic tsunamis (Pattiaratchi and Wijeratne, 2015), have been steadily reported worldwide until recently (Vilibić et al., 2021).

In the eastern Yellow Sea, the most hazardous meteotsunami events on March 31, 2007, and May 4, 2008, caused severe loss of human life and property (Kim et al., 2019). The meteotsunami event on March 31, 2007, was an event in which dangerous wave heights in the range of 1-3 m at most tide gauges were detected from midnight to dawn (Choi et al., 2008). With a similar phase relationship and spatial scale to the meteotsunamis, significant pressure disturbances (rate of pressure change of 1.7-4.8 hPa/10 min) propagated to multiple meteorological stations (Eom et al., 2012; Kim et al., 2019). It was the event that occurred with the strongest intensity in the largest area of the meteotsunami events reported in the Yellow Sea so far, and if there was any meteotsunami monitoring system, the damage could be reduced. In the following year, at noon on Sunday (long weekend), May 4, 2008, 24 fishing people near a breakwater swept away by sudden meteotsunamis, which caused human casualties ( 9 dead and 15 injured). This event suggests that the timing of meteotsunami occurrence is an important factor that can determine the level of human casualties. The sea level oscillations observed at tide gauges near the accident site were not significantly amplified (Choi and Lee, 2009), but the maximum wave height of the accident site measured from coastal videos (CCTV cameras) was about $1.3 \mathrm{~m}$ (Yoo et al., 2010). Although relatively weak pressure disturbances (1.8$1.9 \mathrm{hPa} / 10 \mathrm{~min}$ ) of a local spatial scale were found to be related to the meteotsunamis (Kim et al., 2019), the mechanism for generating such amplified waves near the coastal area at that time remains unknown. The danger of the potential coastal hazards caused by the meteotsunamis began to be known to the Korean public as the damage situation captured by CCTV cameras was 50 released to the media later. Overall, to date, a number of previous studies in the eastern Yellow Sea have been focused on finding out the causes of the accident events in which human and property damage were reported. The potential meteotsunami occurrences that did not cause notable damage can exist besides the accident events.

Understanding the temporal and spatial trends in meteotsunami occurrence is important to prevent and prepare for potential coastal hazards (Linares et al., 2016). Accordingly, there have been attempts to develop a monitoring system for meteotsunami disaster prevention by finding favourable conditions for the meteotsunami occurrence vulnerable to specific times and spaces in each study area. Recent studies have been performed to find the favourite conditions that can cause potential meteotsunamis under various atmospheric conditions since meteotsunamis are related to air-sea interaction (especially corresponding to the 1st and 2nd stages of the mechanism mentioned above). For example, the monitoring possibility was suggested based on correlations between synoptic atmospheric patterns and wave heights observed in the strongest 60 meteotsunami events of the Balearic Islands, the Mediterranean, and the English Channel (Jansà et al., 2007; Šepić et al., 2012; Ozsoy et al., 2016; Vilibić et al., 2018). As a more realistic and quantitative approach, from the perspective of real-time assessment using the existing meteorological stations in the Adriatic Sea, it was demonstrated that appropriate warning can be issued by relating the characteristics of pressure disturbances (e.g., intensity, speed, incoming direction) to the 5 level of a 
meteotsunami danger (Šepić and Vilibić, 2011). An attempt was made to suggest common storm structures favourable to meteotsunami occurrence in Lake Michigan by using not only meteorological station data but also temporal and spatial patterns of reflectivity on radar images (Bechle et al., 2015). In addition, numerical model runs have been conducted to assess the vulnerability and risks in the coastal area for various propagation scenarios of atmospheric disturbances (Linares et al., 2016; Šepić et al., 2015b; Vilibić et al., 2005).

For meteotsunami disaster prevention in the Yellow Sea, a real-time pressure disturbance monitoring system was developed in 2018 and pilot-tested by the Korea Meteorological Administration (KMA). The monitoring system is characterized by determining the possibility of meteotsunami occurrence based on the intensity and speed of pressure disturbance observed from 89 meteorological stations (Kim et al., 2021). However, since there was no previous study on temporal patterns in meteotsunami occurrence in the Yellow Sea, the operation of the monitoring system was limited to MarchApril with reference to the month of the strongest meteotsunami event on March 31, 2007. It is quite inefficient for the KMA that monitors various natural hazards in real time to operate the meteotsunami monitoring system 365 days a year with limited manpower and resources. Moreover, the real-time decision-making process during the test operation was only possible to be based on a dichotomous decision (occurrence/non-occurrence) because there was no risk level assessment of meteotsunami occurrence. The two-choice decision-making allows the monitoring system operator to make quick and easy decisions, but on the other hand, it can cause frequent false alarms (especially false negatives). Therefore, specific guidelines and recommendations based on the characteristics of the meteotsunami events are required in terms of future operational efficiency and risk level assessment. The risk level assessment needs to be performed to make more accurate judgments by outlining the probability of the meteotsunami for each condition of pressure disturbance.

The objective of this paper is to quantify the occurrence frequency and favourable conditions (i.e., vulnerable conditions) of the pressure-forced meteotsunami events in the eastern Yellow Sea over the past decade (2010-2019). In

85 particular, these results can be used as guidelines and recommendations when operating the real-time monitoring system: (i) operation period; (ii) potential hot spot; and (iii) risk levels of meteotsunami occurrence based on the characteristics of pressure disturbance.

\section{Observation system and pressure jump}

The meteorological station data covering the period of 2010 to 2019 were taken from 89 automatic weather stations (AWSs) utilized in the pressure disturbance monitoring system (Fig. 1). We used the mean sea level pressure recorded at 1 min intervals to calculate the pressure disturbance. Of the 89 AWSs, 17 AWSs, which are acting as a kind of beacon, are located on offshore islands along the eastern Yellow Sea. They allow for earlier observations of the pressure disturbances and thus for preliminary warnings. The remaining 72 AWSs, which detect the propagation (direction and speed) of the pressure disturbances, were located along the eastern coast of the Yellow Sea, including Jeju Island. Radar images covering the area of the AWSs were used to estimate the propagation and spatial scale of the pressure disturbances over time. In addition, 16 tide gauges were 
(1)

selected based on data collection percentage of sea level records during the 10 years (Fig. 1 and Table 1). The sea level data were sampled at $1 \mathrm{~min}$ intervals equal to the sampling interval of the pressure data. Note that the observation system in this study was divided into five latitude bands (Lat.) to assess the spatial occurrences of the pressure-forced meteotsunamis. In order to assign the same number of tide gauges as possible to each latitude band, the TA tide gauge was assigned to Lat. A, and the CJ tide gauge was assigned to Lat. D (Table 1). The tide gauges located in Lat. A showed relatively lower data collection percentages than other tide gauges, as the starting year of observation was delayed to 2012 .

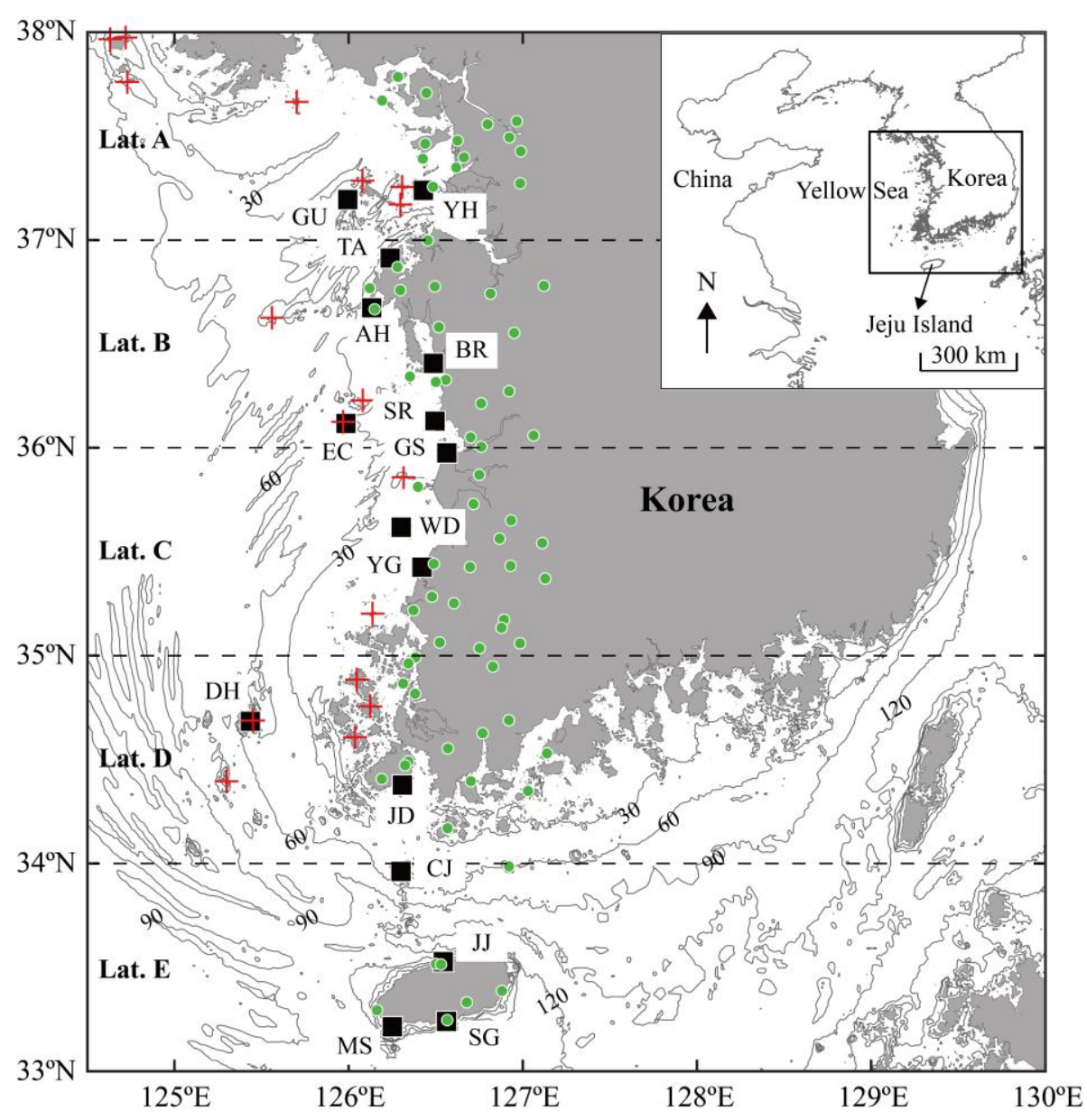

Figure 1: Depth contours (m), locations of 89 automatic weather stations (AWSs) indicated with crosses and green dots, and 16 tide gauges indicated with black squares along the eastern Yellow Sea. Red crosses mark 17 AWSs in caution zone, which are beacons of real-time pressure disturbance monitoring system. Green circles mark $72 \mathrm{AWSs}$ in warning zone for a timely warning near the coast. Observation system was divided into five latitude bands: Lat. A (37-38 $\mathrm{N})$, Lat. B (36-37 $\left.{ }^{\circ} \mathrm{N}\right)$, Lat. C (35-36 $\left.{ }^{\circ} \mathrm{N}\right)$, Lat. D $(34-$ $\left.35^{\circ} \mathrm{N}\right)$, and Lat. $\mathrm{E}\left(33-34^{\circ} \mathrm{N}\right)$. 
110 Table 1: Latitude bands, location, and data collection percentage of tide gauges.

\begin{tabular}{|c|c|c|c|c|}
\hline $\begin{array}{l}\text { Latitude band } \\
\text { (Lat.) }\end{array}$ & $\begin{array}{l}\text { Longitude } \\
\qquad\left({ }^{\circ} \mathrm{E}\right)\end{array}$ & $\begin{array}{l}\text { Latitude } \\
\qquad\left({ }^{\circ} \mathrm{N}\right)\end{array}$ & Location & $\begin{array}{c}\text { Data collection } \\
\qquad(\%)\end{array}$ \\
\hline \multirow{3}{*}{ Lat. A } & 126.4286 & 37.2386 & YeongHeungdo (YH) & 79 \\
\hline & 125.9950 & 37.1944 & GulUpdo (GU) & 72 \\
\hline & 126.2389 & 36.9131 & TaeAn (TA) & 78 \\
\hline \multirow{4}{*}{ Lat. B } & 126.1323 & 36.6737 & AnHeung (AH) & 97 \\
\hline & 126.4861 & 36.4064 & BoRyeong (BR) & 89 \\
\hline & 125.9848 & 36.1289 & SeochunmaRyang (SR) & 80 \\
\hline & 126.4953 & 36.1173 & EoChungdo (EC) & 97 \\
\hline \multirow{3}{*}{ Lat. C } & 126.5631 & 35.9755 & GunSan (GS) & 99 \\
\hline & 126.3017 & 35.6181 & WiDo (WD) & 78 \\
\hline & 126.4207 & 35.4262 & YeongGwang (YG) & 96 \\
\hline \multirow{3}{*}{ Lat. D } & 125.4356 & 34.6842 & DaeHeuksando (DH) & 98 \\
\hline & 126.3086 & 34.3777 & JinDo (JD) & 98 \\
\hline & 126.3001 & 33.9618 & ChuJado (CJ) & 99 \\
\hline \multirow{3}{*}{ Lat. E } & 126.5432 & 33.5275 & JeJu (JJ) & 97 \\
\hline & 126.5616 & 33.2400 & SeoGwipo (SG) & 99 \\
\hline & 126.2512 & 33.2143 & MoSeulpo (MS) & 98 \\
\hline
\end{tabular}

Meteotsunami is initiated by a traveling pressure disturbance that changes rapidly during a short period of time (Hibiya and Kajiura, 1982; Monserrat et al., 2006). Accordingly, calculation and threshold of the pressure disturbance can be important parts of meteotsunami monitoring. In this study, the pressure disturbance is the rate of pressure change, which known 115 as a pressure tendency (Šepić et al., 2009b; Šepić and Vilibić, 2011). The pressure disturbance at every 1 min interval was calculated by moving the $10 \mathrm{~min}$ rates of pressure change, similar to the moving average method. The minimum intensity of the pressure disturbances was examined during the meteotsunami events to find out which intensity of the pressure disturbance can generate the meteotsunamis in the Yellow Sea. The referenced meteotsunami events include the events that were revealed due to the severe accidents and captured by the KMA real-time monitoring system in 2018 (Kim et al., 2021). The intensity

120 was known to exceed $1.5 \mathrm{hPa} / 10 \mathrm{~min}$ in common in the meteotsunami events (Kim et al., 2019). Therefore, we considered a pressure disturbance exceeding $1.5 \mathrm{hPa} / 10$ min to be a pressure jump that can generate potential meteotsunamis in the Yellow Sea. 


\section{Classification of pressure-forced meteotsunami dates}

\subsection{Characteristics of the accident events}

125 A meteotsunami event on April 26, 2011, was a relatively veiled event compared to the most hazardous meteotsunami events before 2010 (31/03/2007, 04/05/2008). In particular, it was the meteotsunami event of accident since 2010, which caused significant property damage to fishing boats and fish farms in the DaeHeuksando (DH) harbour (Kim et al., 2016). The sea level pressure, pressure disturbance, sea level, and high-frequency sea level observed from the AWS and tide gauge (Fig. 1) located in the DH harbour are shown in Fig. 2. In general, meteotsunamis are distributed in the same frequency range as the

130 tsunami frequency band (Monserrat et al., 2006), and the sea level oscillations observed during the meteotsunami events of accidents in the Yellow Sea (Choi et al., 2008; Choi and Lee, 2009; Eom et al., 2012; Kim et al., 2014) were also distributed in high-frequency bands (period of less than $2 \mathrm{~h}$ ). The daily maximum amplitude of the high-frequency sea level (Fig. 2d) was accompanied by a pressure jump (Fig. 2b), which means the inverted barometer response. Also, the daily maximum amplitudes were detected sequentially in multiple tide gauges along the propagation path of the pressure jumps. We can find out the following common characteristics of the pressure-forced meteotsunami in the meteotsunami events of the accident:

- $\quad$ phase relationship between pressure jump and high-frequency sea level (Kim et al., 2019); and

- $\quad$ spread of daily maximum amplitudes to multiple tide gauges, more than three tide gauges (Kim et al., 2020).

After the time of the accident, a stronger group of pressure jumps (Fig. 2a) was detected, but the sea level oscillations were observed with much smaller amplitudes (Fig. 2c). It is suspected that the favourable conditions of pressure jump for meteotsunami occurrence could be not only the intensity, but also other characteristics of pressure jump, or wave interference conditions. 

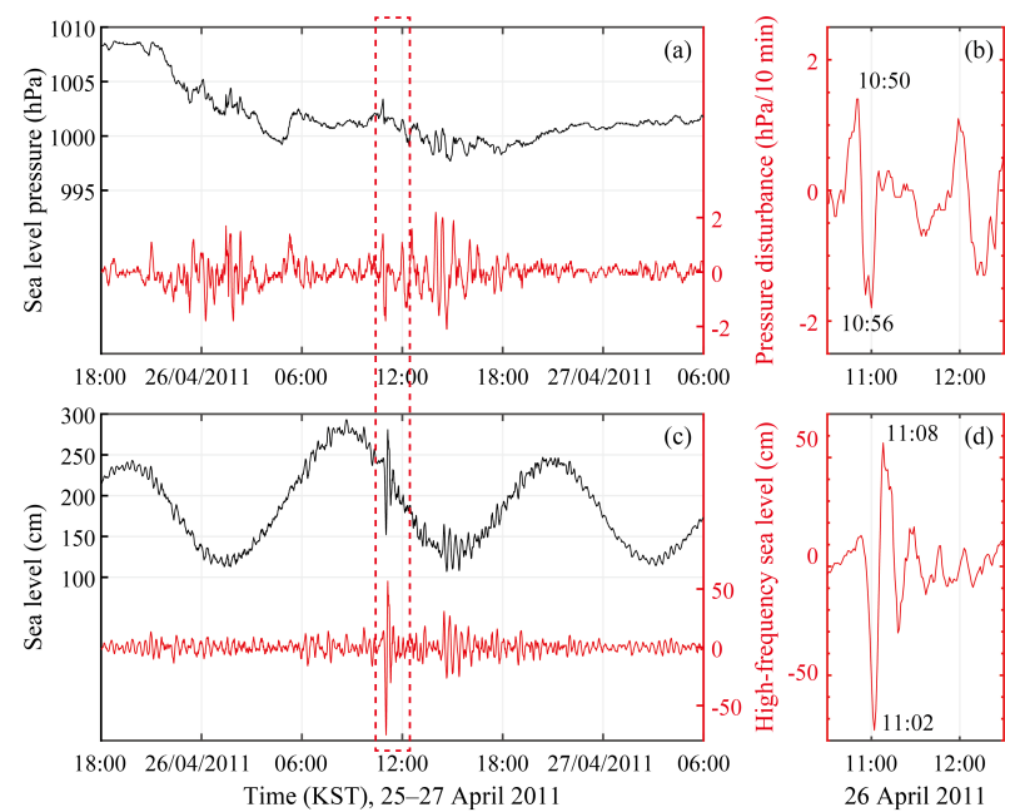

Figure 2: Pressure-forced meteotsunami event of accident from the DaeHeuksando (DH) harbour (see Table 1) on 25-27 April 2011: (a) sea level pressure and pressure disturbance with $36 \mathrm{~h}$ record, (b) pressure disturbance with $2 \mathrm{~h}$ record for clarity, (c) sea level and high-frequency sea level with $36 \mathrm{~h}$ record, and (d) high-frequency sea level with $2 \mathrm{~h}$ record for clarity. Square highlights time of accident during 2 h.

We need to check what daily maximum amplitude should be considered as a meteotsunami. As shown in Fig. 3, the meteotsunami amplitude threshold was determined based on box and whisker plots for the daily maximum amplitudes of the high-frequency sea level over the last 10 years, which can provide more detailed information about the distribution of the data. Since each site has different levels of background noise, each interquartile range (IQR) of the daily maximum amplitudes was different according to tide gauge and latitude band. Assuming normal distribution of the daily maximum amplitudes, the whisker range falls within the range of 2.7 sigma. In this study, we try to determine an amplitude threshold that satisfies about 2-3 sigma of daily maximum amplitudes at as many tide gauges as possible, which is the threshold that exceeds 2 sigma while falling in the whisker range. An absolute amplitude threshold was applied to all tide gauges to avoid filtering out minor events (Monserrat et al., 2006). As a result, the amplitude threshold most satisfying the above-mentioned conditions was selected between the following threshold ranging from $10-20 \mathrm{~cm}$.

- $10 \mathrm{~cm}$ : The amplitude threshold of $10 \mathrm{~cm}$ spans the whisker of all tide gauges, but less than 2 sigma at almost tide gauges.

- $\quad 20 \mathrm{~cm}$ : If this threshold is selected, the biased events can be filtered out only from the tide gauges in Lat. E with high levels of background noise. It is a rigorous amplitude threshold at almost tide gauges in Lat. A-D. 
- $\quad 15 \mathrm{~cm}$ : It is a high threshold for Lat. A with low levels of background noise, and a low threshold for Lat. E. However, when this threshold is applied, the 2-3 sigma amplitude threshold is satisfied at most tide gauges.

165 When determining whether the meteotsunami occurred on the pressure jump events filtered by the monitoring system, the KMA considered the minimum amplitude $(15 \mathrm{~cm})$ of high-frequency sea level oscillations observed during the meteotsunami events of the accident as the meteotsunami amplitude threshold of the Yellow Sea. Therefore, the $15 \mathrm{~cm}$ amplitude, which is most suitable for the suggested conditions and has been used in the KMA, was determined as an intensity threshold of a meteotsunami in this study.

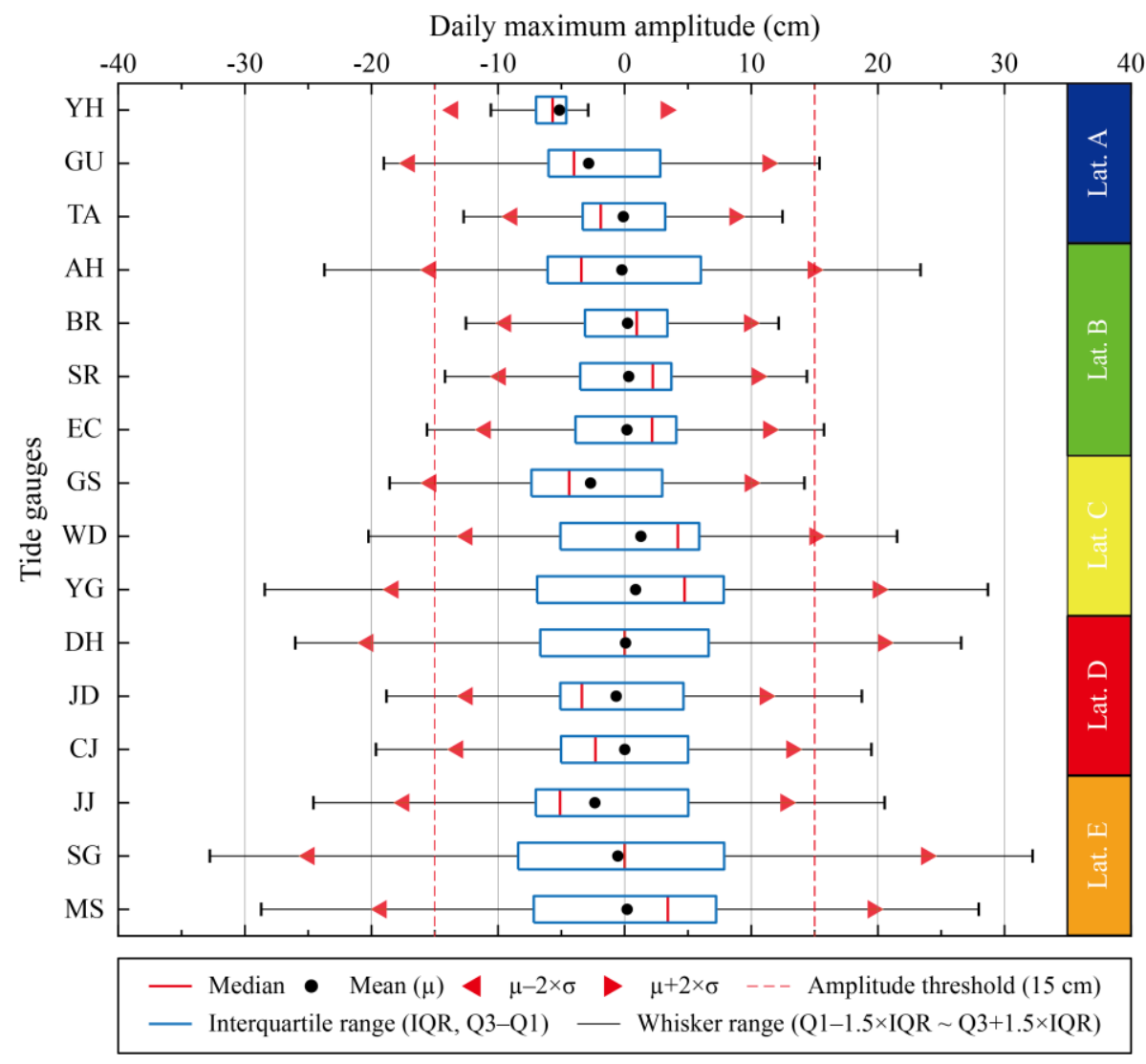

Figure 3: Box and whisker plot for daily maximum amplitude between 2010 and 2019 from 16 tide gauges in five latitude bands. Range of amplitude exceeding two sigma and determined amplitude threshold of meteotsunami are also indicated. 


\section{$175 \quad 3.2$ Process of classifying pressure jump and meteotsunami dates}

The classification of the pressure jump dates was performed through the processes of data collection, pre-processing, determination, and post-processing (Fig. 4). Each daily sample with a data collection percentage of less than $68 \%$ (1 sigma) was excluded when collecting daily samples in the pre-processing step. When analysing the pressure jump dates in the preprocessing and determination steps, we used the following protocols of the current pressure disturbance monitoring system

180 (Kim et al., 2021):

- $\quad$ observation system utilizing 89 AWSs, which are 17 AWSs in caution zone (red crosses in Fig. 1) and 72 AWSs in warning zone (green circles in Fig. 1);

- $\quad$ intensity threshold of pressure jump exceeding $1.5 \mathrm{hPa} / 10 \mathrm{~min}$; and

- $\quad$ propagation of pressure jump at least one AWS in caution zone after at least one AWS in warning zone.

185 As a post-processing step, the propagation patterns of the pressure jump estimated from the multiple AWSs and radar images were double-checked by our visual inspection. Finally, only dates when the two propagation patterns matched were classified as pressure jump dates.

The pressure-forced meteotsunami events were classified based on the characteristics of the high-frequency sea level, which are (i) co-occurrence with pressure jump and (ii) propagation of daily maximum amplitudes, as mentioned above (Fig.

190 4). Similar to the daily sample analysis of the pressure jump dates, each daily sample of sea level with a high rate of missing data was controlled in the first pre-processing step. To remove influence of long-term variation from the analyses, we have subtracted a daily mean sea level from the daily sample after linear interpolation was used to fill in the missing data. Note that a wavelet filter useful for extracting localized peaks and non-periodic signals (Torrence and Compo, 1998) was used to extract the high-frequency component of sea level oscillations of less than $2 \mathrm{~h}$. Spurious peaks due to the missing data were eliminated

195 based on visual inspection. Then, the maximum amplitude of the high-frequency sea level for each daily sample can be obtained. If the daily maximum amplitudes that exceeded the intensity of the meteotsunami threshold $(15 \mathrm{~cm})$ were detected at more than three tide gauges of the 16 tide gauges (Fig. 1 and Table 1) on the same date, the date was determined as a meteotsunami date. As a result, we can classify the dates when the pressure jump and meteotsunami occurred together as pressure-forced meteotsunami events. 


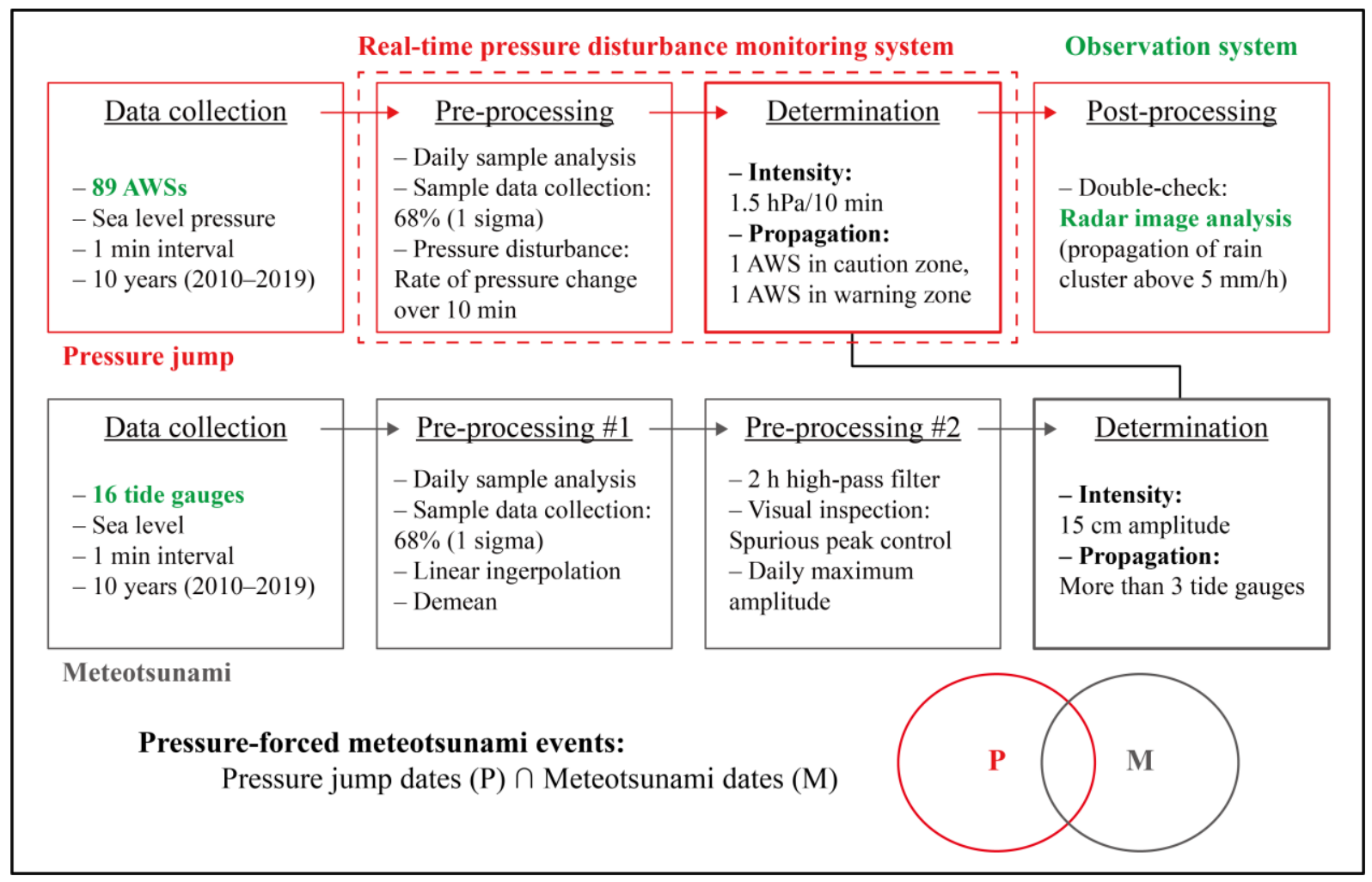

Figure 4: Process flow diagram showing classification of pressure-forced meteotsunami events.

\section{Pressure-forced meteotsunami occurrences}

\subsection{Temporal and spatial occurrences}

Table 2 summarizes the daily maximum amplitudes exceeding the intensity threshold at each tide gauge during the pressureforced meteotsunami events. To examine the validity of the classified 34 pressure-forced meteotsunami events (Table 2 and Fig. 5), we have checked whether the detection of the following reported events since 2010 (Day/Month/Year):

- a. one meteotsunami event of an accident (26/04/2011);

- b. five meteotsunami events revealed by KMA internal reports (04/04/2015, 17/04/2016, 17/05/2018, 20/03/2019, and 09/04/2019); and

- $\quad$ c. two meteotsunami events captured by KMA real-time monitoring system from March-April 2018 (04/03/2018 and 10/04/2018). 
https://doi.org/10.5194/nhess-2021-126

Preprint. Discussion started: 4 May 2021

(c) Author(s) 2021. CC BY 4.0 License.

It was confirmed that the results of the classified events were moderately reasonable in that all the reported events were

captured (Table 2) by using the intensity and propagation thresholds (Fig. 4) based on the common characteristics of the meteotsunami occurrences. Meanwhile, the percentage of unreported meteotsunami events between 2010 and 2019 reached $76 \%$ (Fig. 5).

Table 2: Daily maximum amplitude $(\mathrm{cm})$ exceeding the intensity threshold during pressure-forced meteotsunami events. Meteotsunami event dates are indicated as Day/Month/Year.

\begin{tabular}{|c|c|c|c|c|c|c|c|c|c|c|c|c|c|c|c|c|}
\hline \multirow{2}{*}{ Event date } & \multicolumn{3}{|c|}{ Lat. A } & \multicolumn{4}{|c|}{ Lat. B } & \multicolumn{3}{|c|}{ Lat. C } & \multicolumn{3}{|c|}{ Lat. D } & \multicolumn{3}{|c|}{ Lat. E } \\
\hline & $\mathrm{YH}$ & GU & $\mathrm{TA}$ & $\mathrm{AH}$ & $\mathrm{BR}$ & SR & $\mathrm{EC}$ & GS & WD & YG & $\mathrm{DH}$ & JD & CJ & $\mathrm{JJ}$ & SG & MS \\
\hline $10 / 02 / 2010$ & - & - & - & 19.3 & - & - & - & 28.2 & - & - & 22.7 & 17.0 & 21.0 & - & - & 33.3 \\
\hline $11 / 02 / 2010$ & - & - & - & - & - & - & - & - & - & - & 26.3 & 15.8 & 30.2 & - & 31.0 & 38.2 \\
\hline $01 / 03 / 2010$ & - & - & - & 15.0 & - & - & 19.7 & - & - & - & 20.5 & - & 28.1 & - & - & 23.0 \\
\hline $20 / 03 / 2010$ & - & - & - & 17.4 & - & - & 19.7 & - & - & - & - & - & - & - & - & 15.4 \\
\hline $22 / 03 / 2010$ & - & - & - & - & - & - & - & - & - & - & 19.1 & 18.8 & 18.8 & - & - & - \\
\hline $21 / 04 / 2010$ & - & - & - & 18.0 & - & - & 17.3 & 20.9 & - & - & - & - & - & - & - & - \\
\hline $24 / 05 / 2010$ & - & - & - & - & - & - & - & - & - & - & 39.5 & 22.4 & 29.1 & - & 29.4 & 20.7 \\
\hline $26 / 04 / 2011^{\mathrm{a}}$ & - & - & - & - & - & - & 25.6 & - & - & - & 75.3 & - & 24.8 & - & - & 28.1 \\
\hline $30 / 04 / 2011$ & - & - & - & 21.9 & 15.1 & - & 22.9 & - & - & - & 23.4 & - & - & - & - & 20.2 \\
\hline $21 / 05 / 2011$ & - & - & - & 22.9 & - & - & 23.5 & 18.6 & - & - & - & - & - & - & - & - \\
\hline 08/06/2011 & - & - & - & 18.7 & - & - & 25.6 & 18.8 & - & - & 23.0 & - & - & - & 15.7 & - \\
\hline 03/04/2012 & - & - & - & - & - & - & - & - & - & - & 15.1 & 19.9 & - & - & 22.7 & 37.9 \\
\hline 05/07/2012 & - & - & - & - & - & 15.9 & 19.7 & 19.1 & - & - & - & - & - & - & - & - \\
\hline $05 / 12 / 2012$ & - & - & - & - & - & - & - & - & 15.8 & - & 16.1 & - & - & - & 19.1 & - \\
\hline 03/02/2013 & - & - & - & - & - & - & - & - & - & - & 21.1 & 21.6 & 15.6 & - & 15.6 & 34.2 \\
\hline $14 / 04 / 2013$ & - & - & - & - & - & 44.5 & 34.4 & - & 32.9 & - & 20.0 & - & - & - & - & - \\
\hline $10 / 08 / 2013$ & 31.5 & - & 22.0 & - & - & 15.6 & 21.3 & - & 17.1 & - & - & - & - & - & - & - \\
\hline $30 / 11 / 2014$ & - & - & - & - & - & - & - & - & - & - & - & 16.7 & 16.8 & - & 23.6 & - \\
\hline $04 / 04 / 2015^{\mathbf{b}}$ & - & - & - & 35.9 & - & 17.1 & - & - & 16.4 & 27.1 & 21.9 & 16.0 & - & - & 19.3 & 22.4 \\
\hline $12 / 05 / 2015$ & - & 19.8 & - & 22.3 & - & 18.8 & - & - & 18.6 & 23.1 & 20.1 & - & - & - & 19.9 & - \\
\hline $11 / 08 / 2015$ & - & - & - & - & - & - & - & - & - & 19.1 & - & - & - & 18.1 & - & 16.9 \\
\hline $17 / 04 / 2016^{\mathbf{b}}$ & - & - & - & 23.7 & - & - & - & - & - & 20.1 & - & - & - & - & 21.7 & - \\
\hline $15 / 06 / 2016$ & - & - & - & 22.6 & - & - & - & - & 18.2 & 17.1 & 18.5 & - & - & - & - & - \\
\hline $24 / 06 / 2016$ & - & - & - & 23.4 & - & - & - & - & 17.2 & 23.5 & 26.0 & - & - & - & - & - \\
\hline $04 / 03 / 2018^{c}$ & - & - & - & 24.3 & - & - & 27.1 & 29.2 & 35.6 & 45.3 & 28.8 & 16.9 & - & - & - & 19.2 \\
\hline $10 / 04 / 2018^{c}$ & - & - & - & 21.6 & - & - & 17.6 & - & 15.2 & - & - & - & - & - & - & - \\
\hline
\end{tabular}




\begin{tabular}{|c|c|c|c|c|c|c|c|c|c|c|c|c|c|c|c|c|}
\hline $17 / 05 / 2018^{\mathbf{b}}$ & - & 15.3 & - & 20.0 & - & - & - & - & 16.1 & - & 18.4 & - & - & - & - & - \\
\hline $06 / 10 / 2018$ & - & - & - & - & - & - & - & - & - & - & - & - & 17.7 & 38.3 & 21.7 & 21.3 \\
\hline $20 / 03 / 2019^{b}$ & - & - & - & 21.0 & - & 17.5 & - & - & - & 43.1 & 36.4 & 18.7 & 16.6 & 15.3 & 17.9 & - \\
\hline $30 / 03 / 2019$ & - & 30.7 & - & - & - & - & - & - & - & 16.7 & 15.9 & - & - & - & 16.8 & - \\
\hline $07 / 04 / 2019$ & - & - & - & - & - & - & - & - & - & - & - & 17.6 & 19.6 & 19.9 & 23.1 & 55.8 \\
\hline $09 / 04 / 2019^{b}$ & - & - & - & 24.5 & - & - & 15.7 & - & - & 16.9 & - & - & - & - & - & - \\
\hline $07 / 09 / 2019$ & - & - & - & 27.2 & - & - & 18.9 & - & - & 18.9 & - & 23.9 & 20.6 & - & 25.0 & - \\
\hline $10 / 11 / 2019$ & 16.1 & 22.3 & 16.2 & 23.2 & - & - & 16.3 & - & 19.6 & 21.9 & 16.0 & - & - & - & - & - \\
\hline
\end{tabular}

a: event of accident, b: event revealed by KMA internal reports, c: event captured by KMA real-time monitoring system.

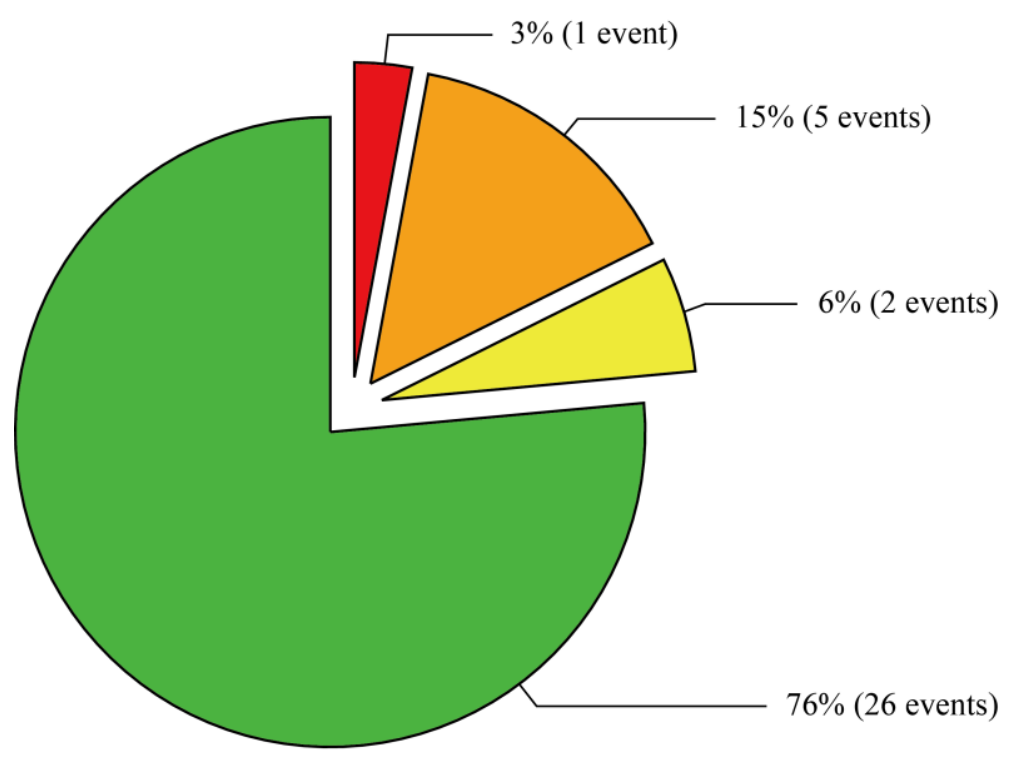

Meteotsunami event of accident (a)

Meteotsunami event revealed by KMA internal reports (b)

Meteotsunami event captured by KMA real-time monitoring system (c)

Unreported meteotsunami event
}

Figure 5: Pie chart of percentage of meteotsunami event types.

The yearly and monthly distribution of events were quantified to examine temporal vulnerability of the pressureforced meteotsunamis in the eastern Yellow Sea (Fig. 6). The meteotsunami occurrences tend to occur not steadily every year but concentrated in some specific years (Fig. 6a). Even one meteotsunami was not detected in 2017, but more than six 
meteotsunamis were detected in 2010 and 2019. Overall, the number of yearly meteotsunami occurrences gradually decreased after 2010, which was the most frequent year, and then increased again from 2018. Based on this irregular pattern of the yearly meteotsunami occurrences, it was difficult to suggest how many meteotsunamis occur each year, at least or on average. On the other hand, the monthly distribution of events showed a strong seasonal trend (Fig. 6b). Peak meteotsunami occurrences were in April during the Northern Hemisphere spring season, with nearly 30\% of events. The meteotsunami events were also distributed intensively in March-May, which were the same months as the announced meteotsunami accidents (31/03/2007,

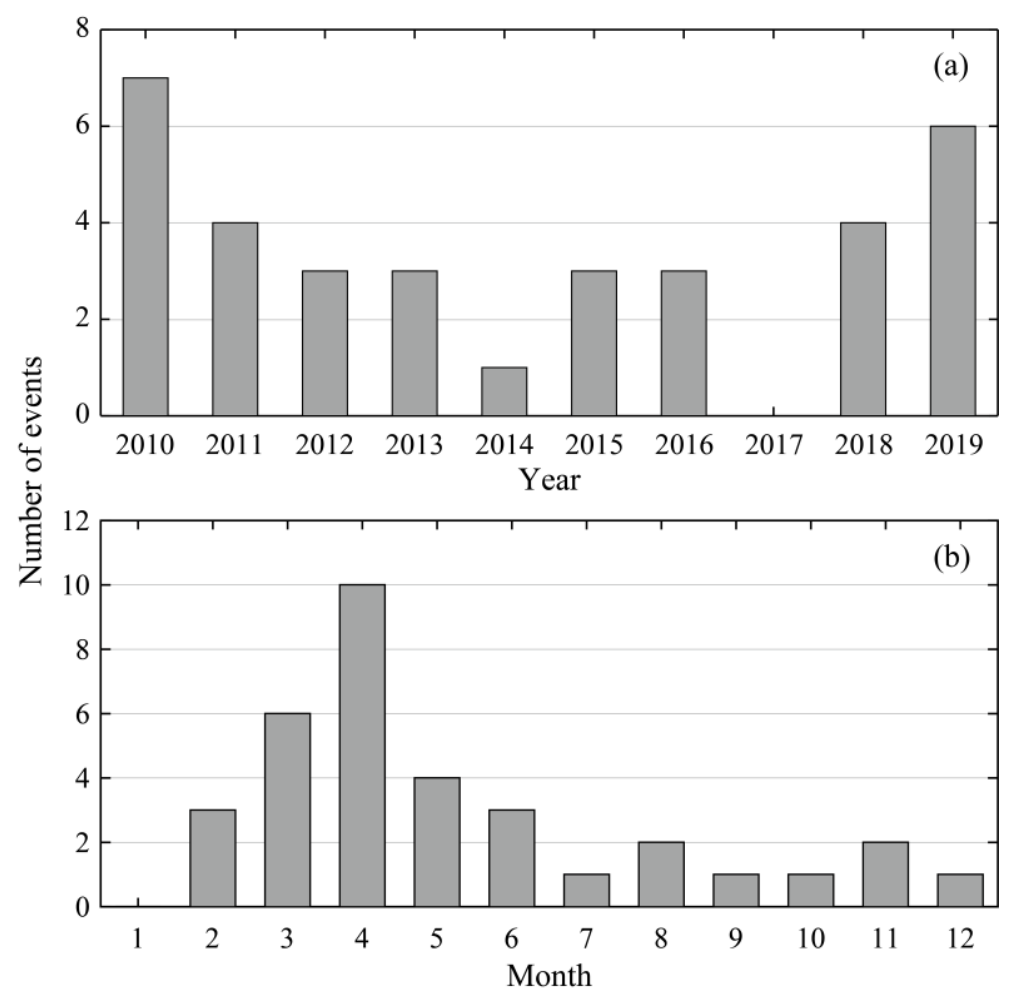

Figure 6: Distribution of meteotsunami events: (a) number of events per year and (b) number of events per year month.

The spatial vulnerability of the events was examined to find potential hot spot places where destructive meteotsunamis were concentrated at each latitude band and tide gauge (Fig. 7). The frequent meteotsunamis occurred in Lat. B-E, and the occurrence frequency of meteotsunamis at each latitude band and tide gauge showed notable differences. Just one meteotsunami event was detected at the BR tide gauge over the past decade. The BR tide gauge is a site with an extremely low 
level of background noise that has not exceeded $10 \mathrm{~cm}$ except for the event of March 31, 2007, which is the largest meteotsunami event of the accident (Kim et al., 2020). The most frequent meteotsunamis occurred at the AH and DH harbour tide gauges, often followed by meteotsunami-induced harbour seiches (Eom et al., 2012; Kim et al., 2016; Kim and Woo, 2021). In the meteotsunami events of the accidents (31/03/2007, 04/05/2008, and 26/04/2011), significant amplitudes of the meteotsunamis were first recorded at the DH tide gauge (Kim et al., 2020). The DH tide gauge as the westernmost observation point of the eastern coast of the yellow sea (Fig. 1), where first and frequent meteotsunamis were detected, is expected to play a kind of beacon tide gauge under any pressure disturbances conditions.

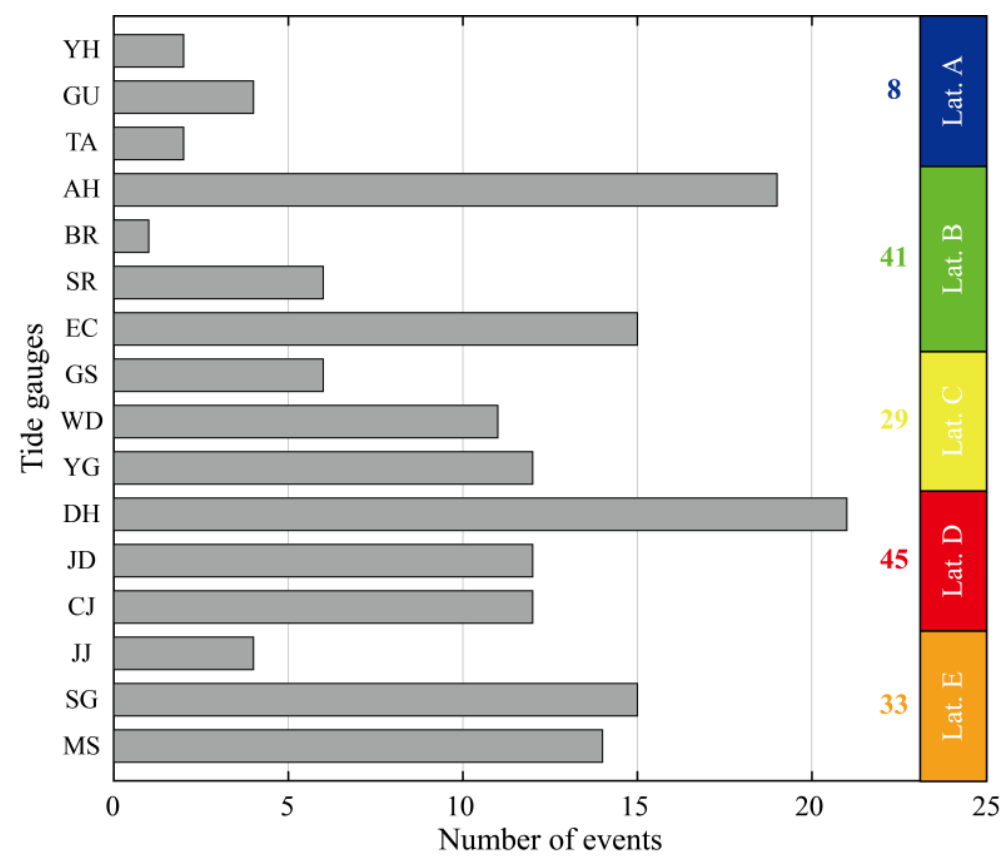

Figure 7: Spatial vulnerability of meteotsunami events per tide gauge and latitude band.

\subsection{Favourable conditions of pressure jump for meteotsunami occurrence}

To find out the favourable conditions of pressure-forced meteotsunami occurrences, the characteristics of the pressure jump were examined for the extreme meteotsunami events of the 34 meteotsunami events (Table 2). The six extreme events were classified by applying the following hazardous conditions in terms of the intensity and occurrence rate of the resultant meteotsunamis (Table 3): 
- average amplitude of the meteotsunami occurred-tide gauges of more than $20 \mathrm{~cm}$;

- meteotsunami occurred-tide gauges of more than six, twice the propagation threshold (Fig. 4); and

- occurrence rate of more than $50 \%$.

The average intensity was calculated by averaging the pressure jump and meteotsunami intensity at only AWSs or tide gauges where the pressure jump-meteotsunami occurred. The occurrence rate in this study was the percentage of the observation points exceeding the intensity threshold of the total observation points satisfying the percentage of sample data collection (Fig. 4) at each event date.

Table 3: Average intensity and occurrence rate of pressure jump and meteotsunami during extreme meteotsunami events. Extreme meteotsunami event dates are indicated as Day/Month/Year.

\begin{tabular}{ccccccc}
\hline \multirow{2}{*}{$\begin{array}{c}\text { Extreme } \\
\text { event date }\end{array}$} & $\begin{array}{c}\text { Pressure jump } \\
\text { Average }\end{array}$ & $\begin{array}{c}\text { Detected } \\
\text { intensity } \\
(\mathrm{hPa} / 10 \mathrm{~min})\end{array}$ & $\begin{array}{c}\text { Occurrence } \\
\text { AWSs }\end{array}$ & $\begin{array}{c}\text { Average } \\
\text { amplitude } \\
(\%)\end{array}$ & $\begin{array}{c}\text { Detected tide } \\
(\mathrm{cm})\end{array}$ & $\begin{array}{c}\text { Occurrence } \\
\text { gauges }\end{array}$ \\
\hline $10 / 02 / 2010$ & 1.8 & $28 / 87$ & 32 & 23.6 & $6 / 8$ & 75 \\
$04 / 04 / 2015$ & 2.7 & $49 / 88$ & 56 & 22.0 & $8 / 13$ & 62 \\
$12 / 05 / 2015$ & 1.7 & $12 / 89$ & 13 & 20.4 & $7 / 12$ & 58 \\
$04 / 03 / 2018$ & 2.6 & $32 / 89$ & 36 & 28.3 & $8 / 11$ & 73 \\
$20 / 03 / 2019$ & 2.5 & $47 / 88$ & 53 & 23.3 & $8 / 11$ & 73 \\
$07 / 09 / 2019$ & 2.1 & $4 / 85$ & 5 & 22.4 & $6 / 11$ & 55 \\
\hline
\end{tabular}

The latitude band-averaged intensity heatmap was compared to confirm the spatial relationship of the pressure jumpmeteotsunami of the extreme meteotsunami events, as shown in Fig. 8. The latitude band below the intensity threshold of pressure jump and meteotsunami are shown as blanks in the heatmap. The intensity ratio of meteotsunami to pressure jump was ranging from 5.6-22.2, showing different intensity ratios according to event and latitude band. Interestingly, the latitude band of the maximum meteotsunami intensity and the latitude band of the maximum pressure jump intensity did not match. The maximum meteotsunami intensity was mainly found nearby the latitude band in which the pressure jump intensity was the maximum. In addition, the latitude band-averaged amplitudes exceeding the intensity threshold of meteotsunami were detected even at the latitude band below the intensity threshold of pressure jump. These discrepancies suggest that the intensity 
https://doi.org/10.5194/nhess-2021-126

Preprint. Discussion started: 4 May 2021

(c) Author(s) 2021. CC BY 4.0 License.
Natural Hazards 웅 and Earth System Sciences

Discussions

of the pressure jump alone is not sufficient to explain the favourable conditions of the pressure jump for meteotsunami occurrence (Šepić and Rabinovich, 2014).

(a) Average intensity of pressure jump $(\mathrm{hPa} / 10 \mathrm{~min})$

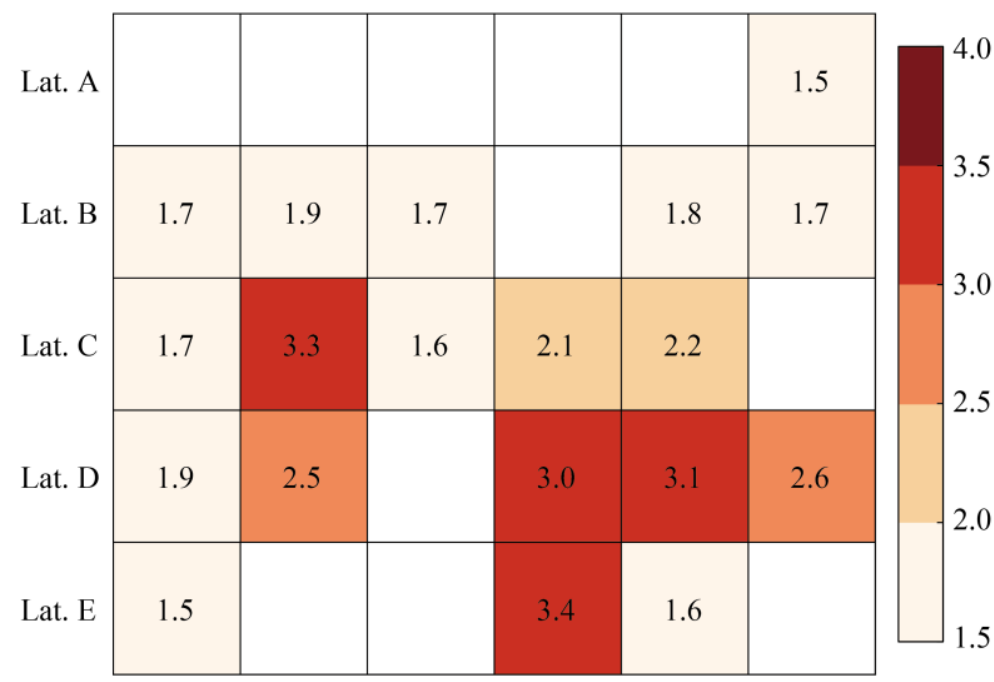

$$
{ }_{10 / 02 / 2010}{ }_{04 / 04 / 2015}^{12 / 05 / 2015} 0_{04 / 03 / 2018}^{20 / 03 / 2019} 07^{109 / 2019} \quad \text { Below }
$$

(b) Average intensity of meteotsunami (cm)

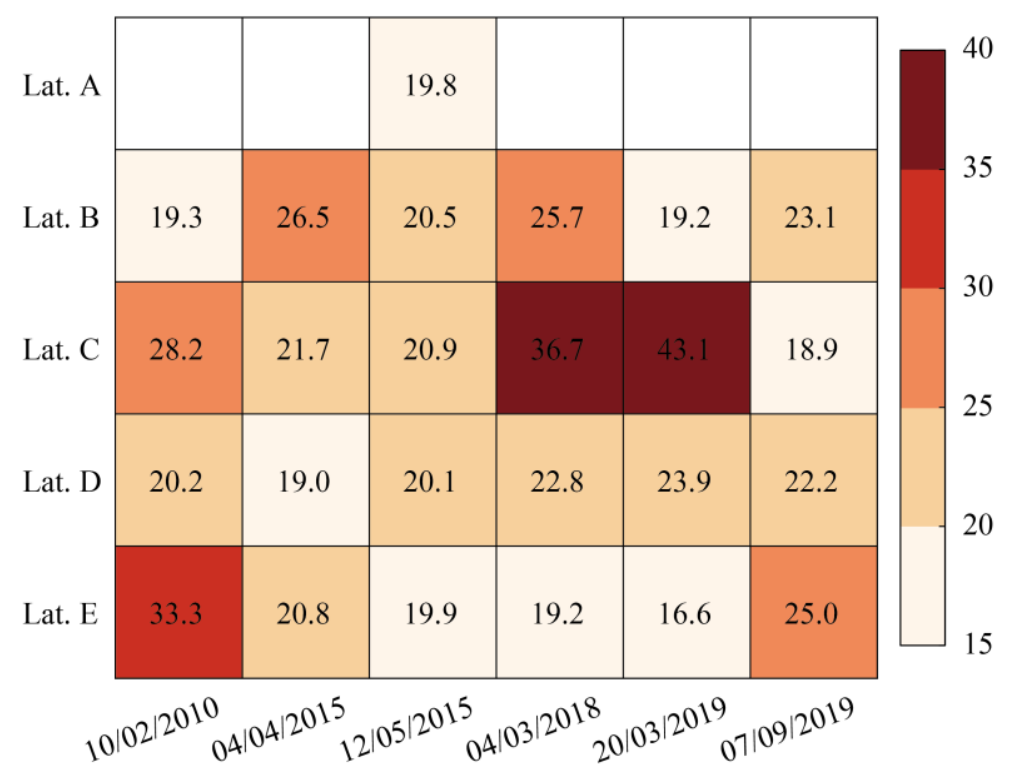

Figure 8: Heatmap of extreme meteotsunami events: latitude band-averaged intensity of (a) pressure jump and (b) meteotsunami. 


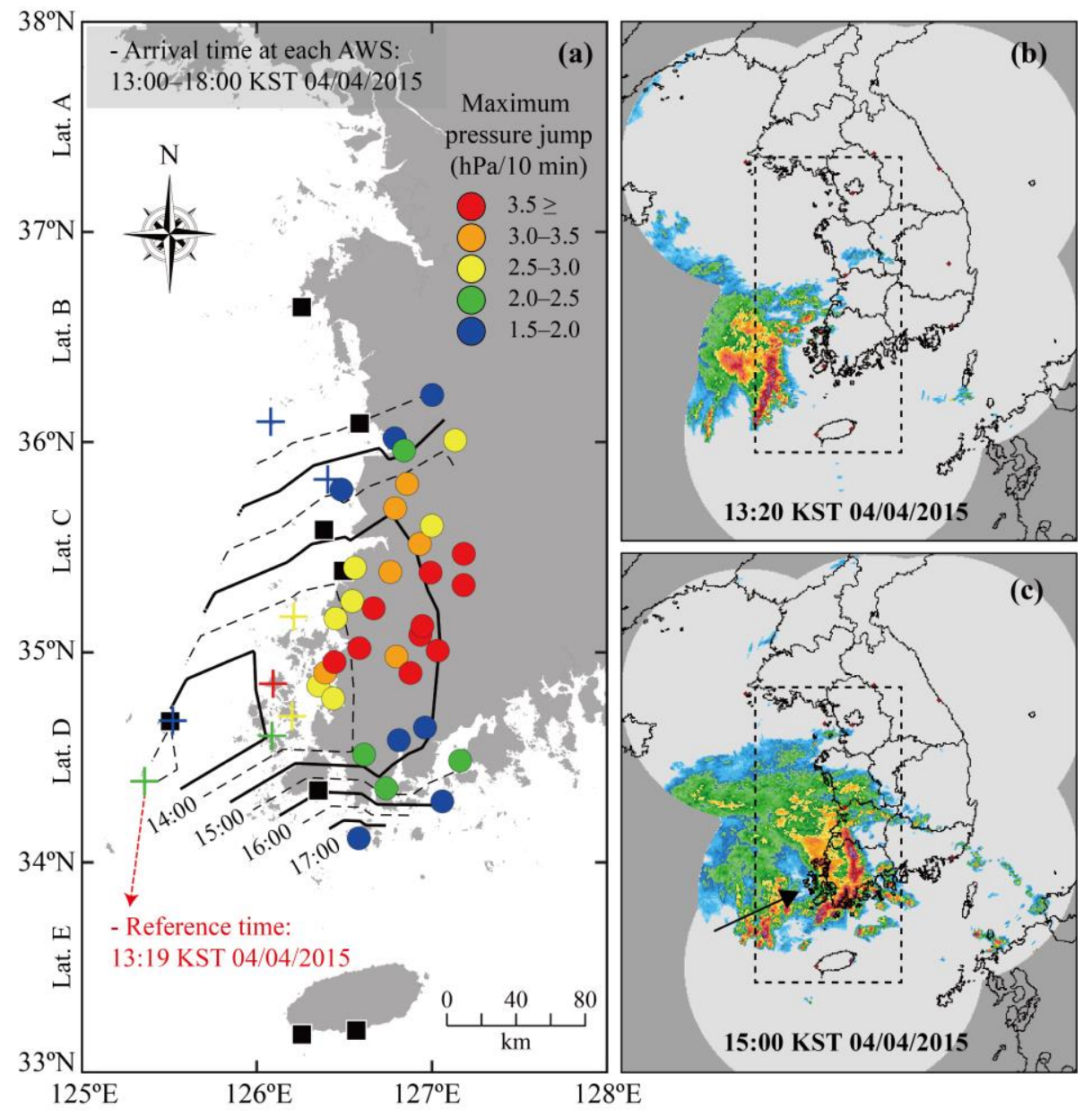

Figure 9: Propagation of the pressure jump on April 4, 2015. (a) Isochrone map. Circles mark multiple AWSs where the pressure jump arrived from 13:00 KST to 18:00 KST. Colors of circles denote the intensity of the maximum pressure jump. Reference time is the first arrival time of the pressure jump in the eastern Yellow Sea. Thick black lines and the black dashed lines indicate isochrones $(1 \mathrm{~h}$ and $30 \mathrm{~min})$ of pressure jump from the reference time. Black squares mark tide gauges where the meteotsunamis arrived (see Table 2). (b-c) radar images at 13:20 and 15:00 KST on April 4, 2015. Square indicates same area of the isochrone map.

When the strong pressure jump with large spatial coverage propagates to multiple stations over several hours, widespread and significantly amplified meteotsunamis can be generated (Hibiya and Kajiura, 1982; Rabinovich et al., 2020; Šepić et al., 2012). To examine how intensity and propagation characteristics of the pressure jump affect meteotsunami occurrence in the Yellow Sea, an example meteotsunami event on 4 April 2015 of the 6 extreme events was selected to compare the temporal and spatial occurrence of pressure jump-meteotsunami. This extreme event (04/04/2015) can be considered as an 
event the most hazardous pressure jump propagated in that the average intensity of the multiple AWSs was almost twice the intensity threshold, and even the occurrence rate exceeded 50\% (Table 3). The resultant meteotsunamis with the average intensity of $22.0 \mathrm{~cm}$ (Table 3) were detected in order of the AH, SR, WD, YG, DH, JD, SG, and MS tide gauges, which are located in Lat. B-E (Table 2). The analysis of the characteristics of the pressure jump that generated the meteotsunamis was based on propagation pattern using the arrival times and the maximum intensity at each AWS (Fig. 9a). The temporal and spatial occurrence of the pressure jump was double-checked by utilizing the radar image corresponding to the arrival time of the pressure jump (Fig. 9b-c). Based on the records of the tide gauges, AWSs, and radar images, we can find the following characteristics of the pressure jump during the extreme meteotsunami event (Table 3 and Fig 9):

- $\quad$ spatial scale (i.e., occurrence rate) of the meteotsunami that was similar to or slightly larger than the spatial scale of the pressure jump;

- propagation of the strong pressure jump to the tide gauges where the destructive meteotsunamis were detected after the reference time when the first pressure jump was detected in the eastern Yellow Sea; and

- $\quad$ similarity in arrival timing and spatial pattern between the intensity of the rain rate and the pressure jump.

310 Likewise, the propagation of the pressure jump and meteotsunami during the rest of the extreme events can be estimated based on the radar images (Fig. 10). The radar image can be used to track the temporal and spatial distribution of the pressure jump since there is a high correlation between the intensity of pressure disturbance and the reflectivity in the radar (Linares et al., 2016; Pellikka et al., 2020; Wertman et al., 2014). As a result, the extreme meteotsunami occurrences were dependent on not only the intensity of the pressure jump but also the propagation pattern, for example, the latitude band of the maximum inten sity 315 (latitude band-averaged amplitude) of meteotsunamis (Fig. 8) tends to be located at the last latitude band along the pressure jump propagation path (Fig. 10). Exceptionally, the extreme meteotsunami event on 7 September 2019 was the meteotsunami event caused by typhoon Lingling (Fig. 10f). It was found that the pressure jump detected around the boundary of the typhoon travelled to the north at a speed below $8 \mathrm{~m} / \mathrm{s}$ with the typhoon. 
https://doi.org/10.5194/nhess-2021-126

Preprint. Discussion started: 4 May 2021

(c) Author(s) 2021. CC BY 4.0 License.

(c) (1)
Natural Hazards 웅 and Earth System

Sciences

Discussions
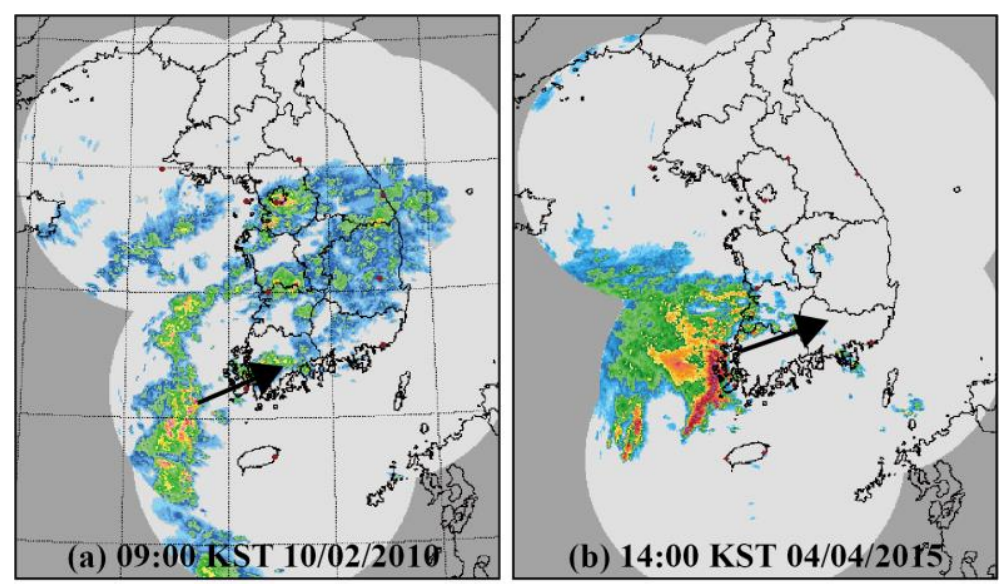

(b) 14:00 KST 04/04/2015 R与

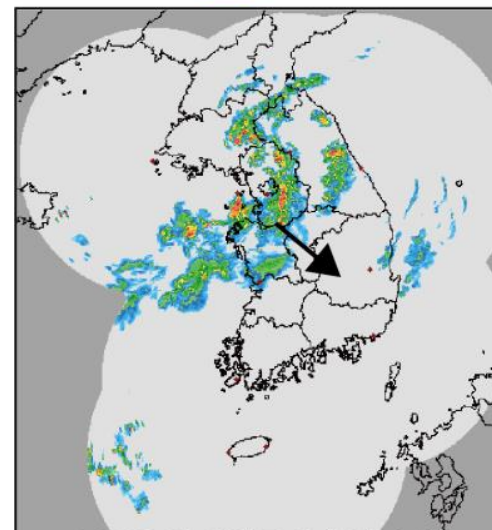

(c) 19:00 KST 12/05/2015

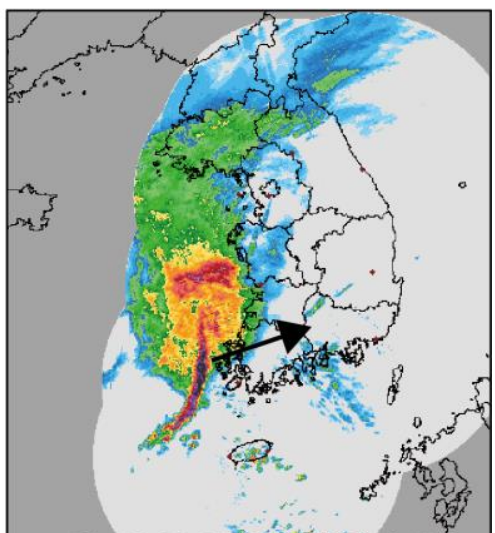

(d) 19:00 KST 04/03/2018

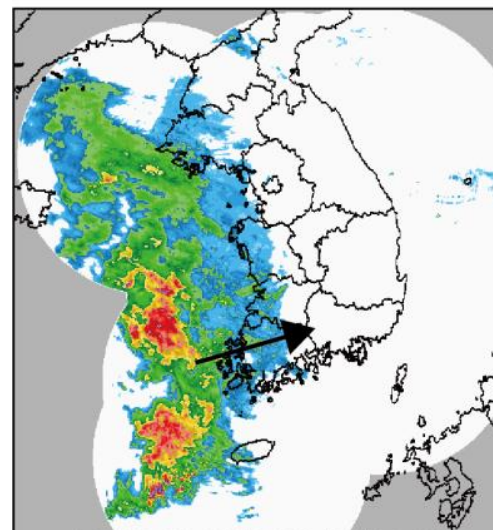

(e) 12:30 KST 20/03/2019 ?
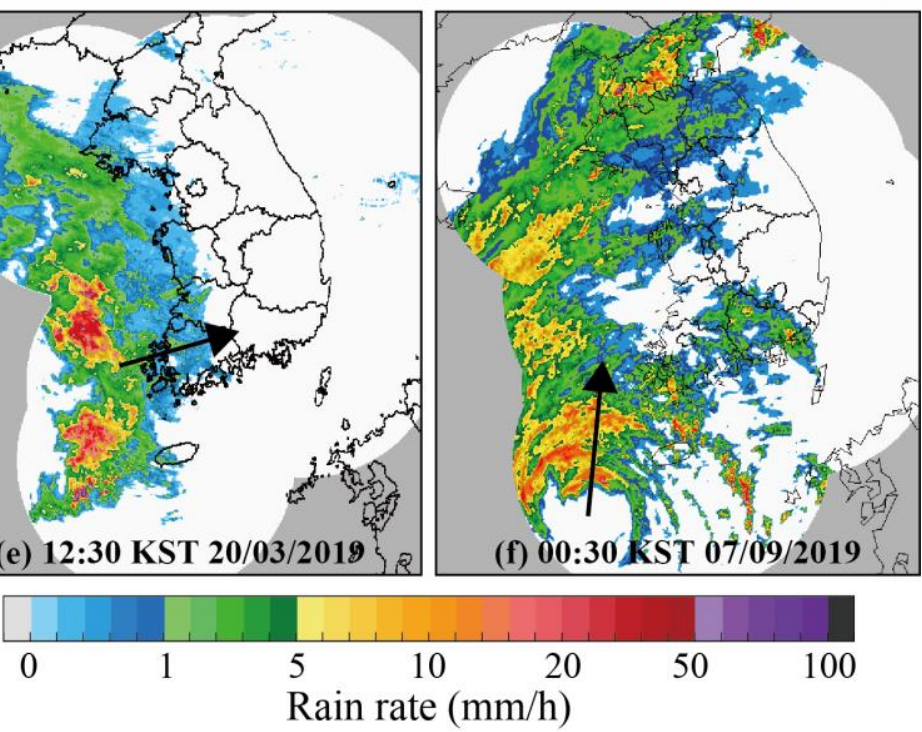

Figure 10: Radar images of extreme meteotsunami events. The propagation direction of pressure jump and rain cluster (above 5 $\mathrm{mm} / \mathrm{h}$ ) is represented with the black arrow. 
In this paper, the intensity of the pressure jump was considered as the key factor for the meteotsunami occurrence, and the favourable conditions for the generation of destructive meteotsunamis were assessed based on the propagation characteristics (speed, direction, and occurrence rate) of the pressure jump. The speed and direction of the pressure jump are favourable conditions for the amplification of the sea level oscillations in the open sea due to the Proudman resonance (Belušić et al., 2007; Chen and Niu, 2018; Proudman, 1929; Vilibić et al., 2004; Vilibić, 2008; Šepić and Vilibić, 2011). The propagation characteristics of the pressure jump on the 34 meteotsunami events can be estimated from the isochrone map of the pressure jump-arrived AWSs in the same way as the analysis of the extreme event on 4 April 2015 (Fig. 9a). However, it was difficult to determine the propagation if there were ambiguous cases due to the cluster-spatial pattern (Fig. 10c) with the low occurrence rate (Table 3) and the multiple propagation pattern. Accordingly, we confirmed the result of the isochrone map, which is consistent with the propagation pattern of the rain rate in radar images by visual inspection.

The results of the pressure jump propagation on each meteotsunami event are shown in Fig. 11 with the scatter points, which indicate speed, direction, and occurrence rate, and two histograms for analysis of the dominant speed and direction. The reported (a-c) and extreme (red) meteotsunami events are highlighted with bold font. The dominant speed and direction of the pressure jump were classified based on the $20 \mathrm{~m} / \mathrm{s}$ speed and the $\mathrm{W}$ direction (histograms and black dashed lines in Fig. 11). Most of the events were dominant in the pressure jump speed ranging from 10-30 m/s (29/34, 85\%). In addition, the events were mainly generated from the pressure jumps propagating from the NW-SW direction (30/34, 88\%). Of the six extreme events, the typhoon-induced event on 7 September 2019 (Fig. 10f) was far from the favourable conditions for the meteotsunami occurrence in terms of the speed, direction, and occurrence rate of the pressure jump. The remaining five extreme events were also included in the above-mentioned dominant pressure jump condition (red dashed square). In particular, the occurrence rates of the pressure jump on the accident event (26/04/2011) and four extreme events (10/02/2010, 04/04/2015, 04/03/2018, and 20/03/2019) were above $30 \%$ in common (Table 3). The four extreme events corresponded to the pressure jump condition ranging from $20-30 \mathrm{~m} / \mathrm{s}$ speed and the SW-W direction. The rest extreme event (12/05/2015), which had the lowest latitude band-averaged amplitude (Table 3), was distributed in the pressure jump condition ranging from $10-20 \mathrm{~m} / \mathrm{s}$ speed and the NW-W direction. 
Occurrence rate $(\%)$
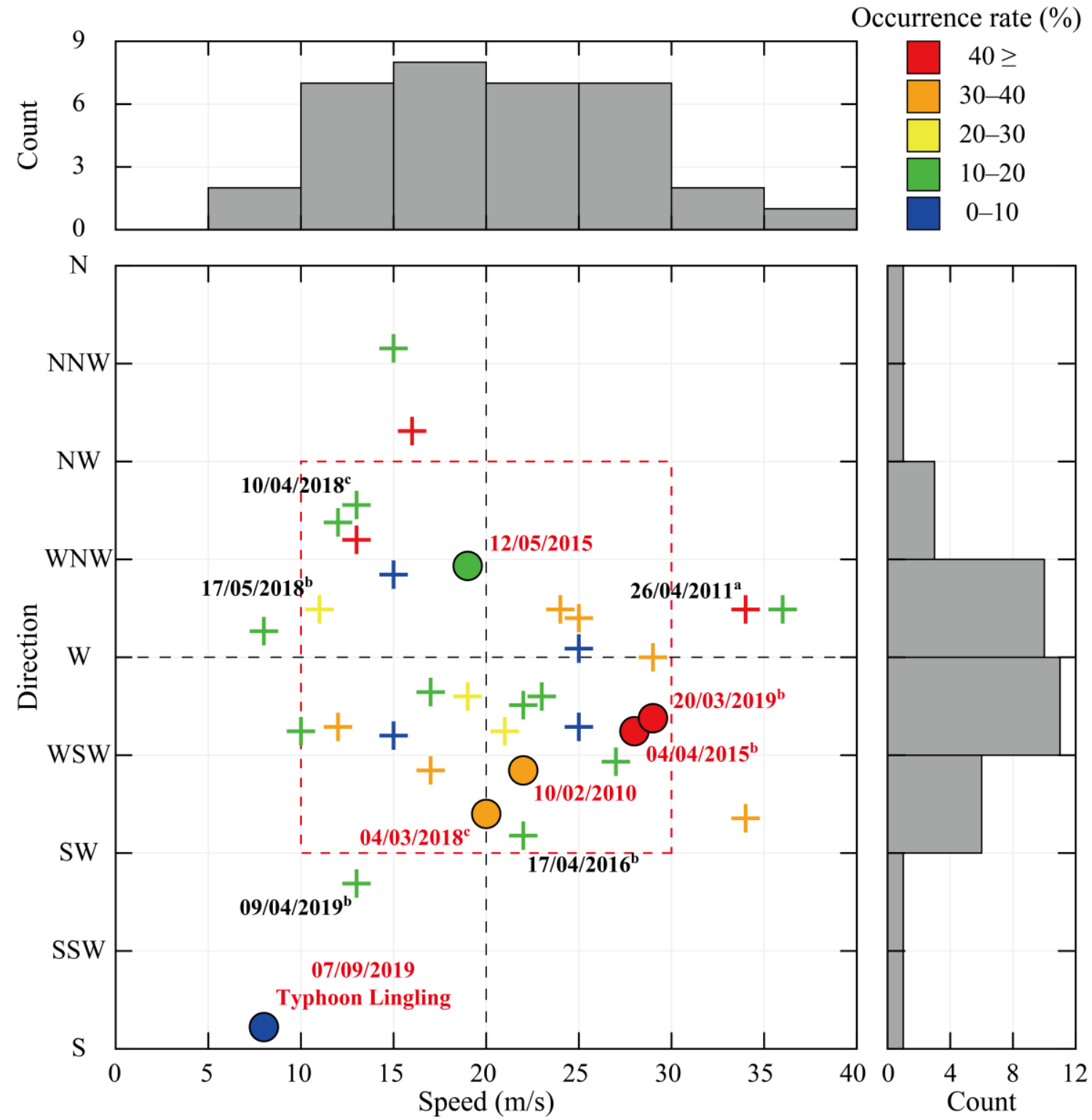

350 Figure 11: Scatter diagram and histograms showing propagation characteristics (speed, direction, and occurrence rate) of pressure jump on 34 meteotsunami events. Red dashed square encloses dominant range of speed and direction of pressure jump. Dominant propagation is divided into four sections by black dashed lines. Reported (a-c) and extreme (red) meteotsunami events are marked.

\section{Discussion and conclusions}

355 We classified the 34 pressure-forced meteotsunami events when the pressure jump dates and the meteotsunami dates intersect by using the long-term pressure and sea level data between 2010 and 2019. The distinct distribution of the meteotsunami 
occurrences per year could not be found in this study, but the causes that were occasionally concentrated in the specific year (Fig. 6a) may be related to the climate variability (Vilibić et al., 2018). 76\% of the classified meteotsunami events (26/34) were concentrated primarily between February and June, during the winter-to-summer transition (Fig. 6b). The eight reported events (Table 2) and the five extreme events excluding the typhoon-induced event (Table 3) also concentrated between February and May. Interestingly, the seasonal patterns in meteotsunami occurrence in the eastern Yellow Sea were similar to Lake Michigan (Bechle et al., 2015), and the peak meteotsunami seasonality in the Mediterranean is found to be between June and August (Rabinovich and Monserrat, 1996; Šepić et al., 2009a; Šepić et al., 2012). The seasonal patterns of event distribution indicate that the observed events are related to atmospheric conditions and processes. In other regions (especially in Europe), the meteotsunami seasonality is associated with some specific synoptic conditions, which can be estimated from a low-pressure system at the surface, horizontal temperature front at $850 \mathrm{hPa}$, and advection by a jet stream wind at $500 \mathrm{hPa}$ (Ozsoy et al., 2016; Šepić et al., 2012; Šepić et al., 2016; Vilibić et al., 2018). Spatially, the frequent meteotsunami occurrences at the DH tide gauge in Lat. D indicates (Fig. 7) that it can be used as a "potential hot spot" for the meteotsunami occurrence along the eastern Yellow Sea. The most probable explanation for this frequent occurrence is due to the dominant direction of the pressure jump from the SW-W direction that can propagate toward Lat. D, as shown in the direction histogram of the pressure jump in Fig. 11. The trends of meteotsunami occurrence and the characteristics of pressure jump favourable to meteotsunami generation derived in this study can be utilized as guidelines for monitoring system operators and policymakers in the eastern Yellow Sea.

The current real-time pressure jump monitoring system in the Yellow Sea has the limitation in determining whether the detected pressure jump can generate the meteotsunami with a dichotomous decision without any risk level assessment (Kim et al., 2021). To assess the risk levels of the pressure jump condition for potential meteotsunami occurrence, we categorized the propagation pattern of the pressure jump on the extreme meteotsunami events (Table 3), which are characterized by more hazardous meteotsunami conditions in terms of the intensity and spatial scale. The most dangerous risk level (the "extreme" risk level in Table 4) for meteotsunami occurrence in the eastern Yellow Sea was determined as the pressure jump condition that occurrence rates are above 30\% high, based on common characteristics of the pressure jump on the accident and extreme events (Fig. 11). The direction and speed of the pressure jump in the open sea can determine the degree of the meteotsunami amplitudes amplified by the Proudman or Greenspan resonance (Monserrat et al., 2006). In addition, as the amplified long ocean waves can travel to multiple harbours along the pressure jump propagation path, the meteotsunami-induced seiches can be accompanied (Rabinovich, 2009). We divided the pressure jump propagation favourable to meteotsunami occurrences into two different ranges of speeds for the dominant directions (the SW-W and NW-W direction). The pressure jump moving from the SW-W direction to the coast at the speed of 20-30 m/s can generate not only the Proudman resonance but also the shelf amplification, as it is likely to pass through rapidly changing depths (with maximum values of 90$120 \mathrm{~m}$ ) and steep bottom slopes in the west of Lat. C-E (Fig. 1). The pressure jump condition was assigned to the "very high" risk level (Table 4), considering that the four extreme events (10/02/2010, 04/04/2015, 04/03/2018, and 20/03/2019) with relatively high latitude band-averaged amplitude (Table 3) are distributed in the corresponding condition (Fig. 11). Another 
pressure jump condition propagating from the NW-W direction and at the speed of 10-20 m/s can be a possibly favourable condition for the Proudman or Greenspan resonance over the region of more shallow depths (with maximum values of 30-60 m) with mild bottom slops in the west of Lat. A-C (Fig. 1). However, the corresponding condition was assigned to the "high" risk level (Table 4). This determination is based on the results that only one extreme event with the low meteotsunami amplitudes is distributed in the pressure jump condition (Fig. 11) and the pressure jump-meteotsunami will propagate at a relatively slow speed. The speed condition of the pressure jump below $5 \mathrm{~m} / \mathrm{s}$ or above $40 \mathrm{~m} / \mathrm{s}$, which was not found on the 34 meteotsunami events (Fig. 11), was classified as the "low" risk level (Table 4) with the lowest probability of the meteotsunami occurrence. And the remaining conditions that were not classified were considered as the "Moderate" risk level (Table 4). When re-operating the monitoring system in the near future, it is necessary to evaluate the accuracy for each risk level, and segmentation of the "Moderate" risk level is required.

Table 4: Guidelines and recommendations for the current meteotsunami monitoring system in the eastern Yellow Sea.

\begin{tabular}{|c|c|c|}
\hline Protocol & Current monitoring system (as-is) & Guidelines and recommendations (to-be) \\
\hline Operation period & 2 months from March-April & 5 months from February-June \\
\hline \multirow[t]{2}{*}{ Potential hot spot } & - & DH tide gauge in Latitude band D \\
\hline & & - Extreme: high occurrence rate above $30 \%$ \\
\hline \multirow{4}{*}{$\begin{array}{l}\text { Risk level of } \\
\text { pressure jump } \\
\text { condition }\end{array}$} & & - Very high: SW-W direction and $20-30 \mathrm{~m} / \mathrm{s}$ speed \\
\hline & - & - High: NW-W direction and 10-20 m/s speed \\
\hline & & - Low: below $5 \mathrm{~m} / \mathrm{s}$ or above $40 \mathrm{~m} / \mathrm{s}$ speed \\
\hline & & - Moderate: other conditions \\
\hline
\end{tabular}

There were exceptional cases other than the 34 pressure-forced meteotsunami events classified in this study. As an exceptional case of the meteotsunami events, there was also a wind-dominated event characterized by sudden and large changes in wind gust speed (5-10 m/s), such as the typhoon-induced meteotsunami (Shi et al., 2020; Anarde et al., 2021) on 7 September 2019 (Fig. 10f). The cases when the pressure jump threshold was not satisfied, but the meteotsunami occurred, may also correspond to wind-dominated meteotsunami events. The contribution of pressure and wind in meteotsunami occurrence can be different by event and study area, normally, it is known that pressure disturbance plays a much larger role in meteotsunami generation (Vilibić et al., 2005; Linares et al., 2016). The contribution of pressure and wind to meteotsunami generation can be different by event and region (Linares et al., 2016), normally, it is known that pressure disturbance plays a much larger role than wind forcings (Vilibić et al., 2005). Conversely, the cases when the strong pressure jumps were detected at multiple AWSs, but the meteotsunami amplitudes were below the threshold can presumably be the effect of interferences 
due to meteotsunami-tide interaction (Choi et al., 2014) or wave-current interaction near the coast (Linares et al., 2019). It seems that false alarms can be reduced by filtering out these exceptional cases as much as possible in the monitoring system. Thus, it is urgent to study the contribution of tide-, winds-, and wave-generated meteotsunami interferences in the eastern Yellow Sea.

Recently, the KMA has been operating a real-time pressure disturbance monitoring system to reduce unexpected damage caused by potential meteotsunami events in the Yellow Sea (Kim et al., 2021). The results obtained in this paper can be applied directly to the monitoring system and provide practical guidelines for the monitoring system operators. In conclusion, the guidelines and recommendations for meteotsunami disaster prevention based on the results of meteotsunami occurrences are suggested in Table 4 when operating the monitoring system. Currently, the monitoring system is operated only in MarchApril due to its operational efficiency and cost (Table 4). However, we suggest that most meteotsunami occurrences can be detected by expanding the intensive operation period to February-June based on the meteotsunami seasonality $(76 \%, 26 / 34)$ over the past ten years (Fig. 6b). It is also required that the two AWSs in caution zone (Fig. 1) located near the DH tide gauge in Lat. D (potential hot spot) need to be monitored intensively (Table 4). Based on the assessed risk levels (Table 4), the monitoring system operator can classify the probability of the meteotsunami occurrences and send warning SMS accordingly. It is expected that the results of spatio-temporal trends in meteotsunami occurrence and favourable conditions of pressure jump (intensity, occurrence rate, and propagation) for meteotsunami generation can be useful and applicable as the monitoring 430 guidelines in the eastern Yellow Sea.

\section{Data availability}

The historical pressure and tide level data used in the current research is available on demand. The radar images can be downloaded from https://www.kma.go.kr/eng/weather/images/radar.jsp.

\section{Competing interests}

435 The authors declare that they have no conflicts of interest.

\section{Acknowledgement}

This research was supported by Basic Science Research Program through the National Research Foundation of Korea (NRF) funded by the Ministry of Education (2019R1A6A3A13097301). 


\section{References}

Anarde, K., Cheng, W., Tissier, M., Figlus, J. and Horrillo, J.: Meteotsunamis Accompanying Tropical Cyclone Rainbands During Hurricane Harvey, J. Geophys. Res. Ocean., 126(1), doi:10.1029/2020JC016347, 2021.

Bechle, A. J., Kristovich, D. A. R. and Wu, C. H.: Meteotsunami occurrences and causes in Lake Michigan, J. Geophys. Res. Ocean., 120(12), doi:10.1002/2015JC011317, 2015.

Belušić, D., Grisogono, B. and Klaić, Z. B.: Atmospheric origin of the devastating coupled air-sea event in the east Adriatic,

J. Geophys. Res. Atmos., 112(17), doi:10.1029/2006JD008204, 2007.

Chen, Y. and Niu, X.: Forced wave induced by an atmospheric pressure disturbance moving towards shore, Cont. Shelf Res., 160, doi:10.1016/j.csr.2018.03.007, 2018.

Choi, B. J., Park, Y. and Kwon, K.: Generation and growth of long ocean waves along the west coast of Korea in March 2007, Ocean Polar Res., 30(4), doi:10.4217/OPR.2008.30.4.453, 2008.

450 Choi, J. Y. and Lee, D. Y.: Analysis of small-scale atmospheric pressure jumps related to the generation of abnormal extreme waves at Boryeong, Ocean Polar Res., 31(4), doi:10.4217/OPR.2009.31.4.379, 2009.

Eom, H.-M., Seung, Y.-H., Woo, S.-B. and You, S.-H.: Analysis of Abnormal Wave at the West Coast on 31 March 2007, J. Korean Soc. Coast. Ocean Eng., 24(3), doi:10.9765/kscoe.2012.24.3.217, 2012.

Hibiya, T. and Kajiura, K.: Origin of the Abiki phenomenon (a kind of seiche) in Nagasaki Bay, J. Oceanogr. Soc. Japan, 38(3), doi:10.1007/BF02110288, 1982.

Jansa, A., Monserrat, S. and Gomis, D.: The rissaga of 15 June 2006 in Ciutadella (Menorca), a meteorological tsunami, Adv. Geosci., 12, doi:10.5194/adgeo-12-1-2007, 2007.

Kim, M.-S. and Woo, S.-B.: Propagation and amplification of meteotsunamis in multiple harbors along the eastern Yellow Sea coast during April 2008, Cont. Shelf Res., 2021. [in progress: minor revision]

460 Kim, H., Kim, Y.-K., Woo, S.-B. and Kim, M.-S.: Atmospheric Analysis on the Meteo-tsunami Case Occurred on 31 March 2007 at the Yellow Sea of South Korea, J. Environ. Sci. Int., 23(12), doi:10.5322/jesi.2014.23.12.1999, 2014.

Kim, M. -S., Eom, H., You, S. H. and Woo, S. -B.: Real-time pressure disturbance monitoring system in the Yellow Sea: pilot test during the period of March to April 2018, Nat. Hazards, 106(2), doi:10.1007/s11069-020-04245-9, 2021.

Kim, M. -S., Kim, H., Eom, H., You, S. H. and Woo, S. -B.: Occurrence of hazardous meteotsunamis coupled with pressure

465 disturbance traveling in the yellow sea, Korea, J. Coast. Res., 91(sp1), doi:10.2112/SI91-015.1, 2019.

Kim, M. S., Eom, H., Lim, E. -P., Lee, C. -K., You, S. H. and Woo, S. -B.: Methodology for detection of a meteotsunami propagation in the Yellow Sea: Reported cases, J. Coast. Res., 95(sp1), doi: 10.2112/SI95-220.1, 2020.

Kim, M. -S., Kim, H., Kim, Y. -K., Gu, B. -H., Lee, H. J. and Woo, S. -B.: Double resonance effect at daeheuksando port caused by air pressure disturbances in Yellow Sea on 31 March 2007, J. Coast. Res., 75(sp1), doi: 10.2112/SI75-229.1, 2016.

470 Linares, Á., Bechle, A. J. and Wu, C. H.: Characterization and assessment of the meteotsunami hazard in northern Lake Michigan, J. Geophys. Res. Ocean., 121(9), doi:10.1002/2016JC011979, 2016. 
Monserrat, S., Vilibić, I. and Rabinovich, A. B.: Meteotsunamis: Atmospherically induced destructive ocean waves in the tsunami frequency band, Nat. Hazards Earth Syst. Sci., 6(6), doi:10.5194/nhess-6-1035-2006, 2006.

Ozsoy, O., Haigh, I. D., Wadey, M. P., Nicholls, R. J. and Wells, N. C.: High-frequency sea level variations and implications for coastal flooding: A case study of the Solent, UK, Cont. Shelf Res., 122, doi:10.1016/j.csr.2016.03.021, 2016.

Pattiaratchi, C. B. and Wijeratne, E. M. S.: Are meteotsunamis an underrated hazard?, Philos. Trans. R. Soc. A Math. Phys. Eng. Sci., 373(2053), doi:10.1098/rsta.2014.0377, 2015.

Pellikka, H., Laurila, T. K., Boman, H., Karjalainen, A., Bjorkqvist, J. V. and Kahma, K. K.: Meteotsunami occurrence in the Gulf of Finland over the past century, Nat. Hazards Earth Syst. Sci., 20(9), doi:10.5194/nhess-20-2535-2020, 2020.

480 Proudman, J.: The Effects on the Sea of Changes in Atmospheric Pressure., Geophys. J. Int., 2, doi:10.1111/j.1365246X.1929.tb05408.x, 1929.

Rabinovich, A. B. and Monserrat, S.: Meteorological tsunamis near the Balearic and Kuril Islands: Descriptive and statistical analysis, Nat. Hazards, 13(1), doi:10.1007/BF00156506, 1996.

Rabinovich, A. B.: Seiches and harbor oscillations, in Handbook of Coastal and Ocean Engineering., 2009.

485 Rabinovich, A. B., Šepić, J. and Thomson, R. E.: The meteorological tsunami of 1 November 2010 in the southern Strait of Georgia: a case study, Nat. Hazards, 106(2), doi:10.1007/s11069-020-04203-5, 2021.

Šepić, J. and Vilibić, I.: The development and implementation of a real-time meteotsunami warning network for the Adriatic Sea, Nat. Hazards Earth Syst. Sci., 11(1), doi:10.5194/nhess-11-83-2011, 2011.

Šepić, J., Denis, L. and Vilibić, I.: Real-time procedure for detection of a meteotsunami within an early tsunami warning 490 system, Phys. Chem. Earth, 34(17-18), doi:10.1016/j.pce.2009.08.006, 2009.

Šepić, J. and Rabinovich, A. B.: Meteotsunami in the Great Lakes and on the Atlantic coast of the United States generated by the "derecho" of June 29-30, 2012, Nat. Hazards, 74(1), doi:10.1007/s11069-014-1310-5, 2014.

Šepič, J., Vilibić, I. and Belušić, D.: Source of the 2007 Ist meteotsunami (Adriatic Sea), J. Geophys. Res. Ocean., 114(3), doi:10.1029/2008JC005092, 2009.

495 Šepic, J., Vilibic, I. and Fine, I.: Northern Adriatic meteorological tsunamis: Assessment of their potential through ocean modeling experiments, J. Geophys. Res. Ocean., 120(4), doi:10.1002/2015JC010795, 2015.

Šepić, J., Vilibić, I., Lafon, A., Macheboeuf, L. and Ivanović, Z.: High-frequency sea level oscillations in the Mediterranean and their connection to synoptic patterns, Prog. Oceanogr., 137, doi:10.1016/j.pocean.2015.07.005, 2015.

Šepić, J., Vilibić, I. and Monserrat, S.: Quantifying the probability of meteotsunami occurrence from synoptic atmospheric 500 patterns, Geophys. Res. Lett., 43(19), doi:10.1002/2016GL070754, 2016.

Ŝepić, J., Vilibić, I. and Strelec Mahovi, N.: Northern Adriatic meteorological tsunamis: Observations, link to the atmosphere, and predictability, J. Geophys. Res. Ocean., 117(2), doi:10.1029/2011JC007608, 2012.

Shi, L., Olabarrieta, M., Nolan, D. S. and Warner, J. C.: Tropical cyclone rainbands can trigger meteotsunamis, Nat. Commun., 11(1), doi:10.1038/s41467-020-14423-9, 2020. 
505 Torrence, C. and Compo, G. P.: A Practical Guide to Wavelet Analysis, Bull. Am. Meteorol. Soc., 79(1), doi:10.1175/15200477(1998)079<0061:APGTWA>2.0.CO;2, 1998.

Vilibić, I.: Numerical simulations of the Proudman resonance, Cont. Shelf Res., 28(4-5), doi:10.1016/j.csr.2007.11.005, 2008. Vilibić, I., Domijan, N. and Čupić, S.: Wind versus air pressure seiche triggering in the Middle Adriatic coastal waters, J. Mar. Syst., 57(1-2), doi:10.1016/j.jmarsys.2005.04.007, 2005.

510 Vilibić, I., Domijan, N., Orlić, M., Leder, N. and Pasarić, M.: Resonant coupling of a traveling air pressure disturbance with the east Adriatic coastal waters, J. Geophys. Res. C Ocean., 109(10), doi:10.1029/2004JC002279, 2004.

Vilibić, I., Monserrat, S. and Rabinovich, A. B.: Meteorological tsunamis on the US East Coast and in other regions of the World Ocean, Nat. Hazards, 74(1), doi:10.1007/s11069-014-1350-x, 2014.

Vilibić, I., Rabinovich, A. B. and Anderson, E. J.: Special issue on the global perspective on meteotsunami science: editorial, 515 Nat. Hazards, 106(2), doi:10.1007/s11069-021-04679-9, 2021.

Vilibić, I., Šepić, J., Dunić, N., Sevault, F., Monserrat, S. and Jordà, G.: Proxy-Based Assessment of Strength and Frequency of Meteotsunamis in Future Climate, Geophys. Res. Lett., 45(19), doi:10.1029/2018GL079566, 2018.

Wertman, C. A., Yablonsky, R. M., Shen, Y., Merrill, J., Kincaid, C. R. and Pockalny, R. A.: Mesoscale convective system surface pressure anomalies responsible for meteotsunamis along the U.S. East Coast on June 13th, 2013, Sci. Rep., 4, 520 doi:10.1038/srep07143, 2014.

Yoo, J., Lee, D. Y., Ha, T. M., Cho, Y. S. and Woo, S. B.: Characteristics of abnormal large waves measured from coastal videos, Nat. Hazards Earth Syst. Sci., 10(4), doi:10.5194/nhess-10-947-2010, 2010. 